Magyar Gyógyszerésztudományi Társaság Gyógynövény Szakosztály

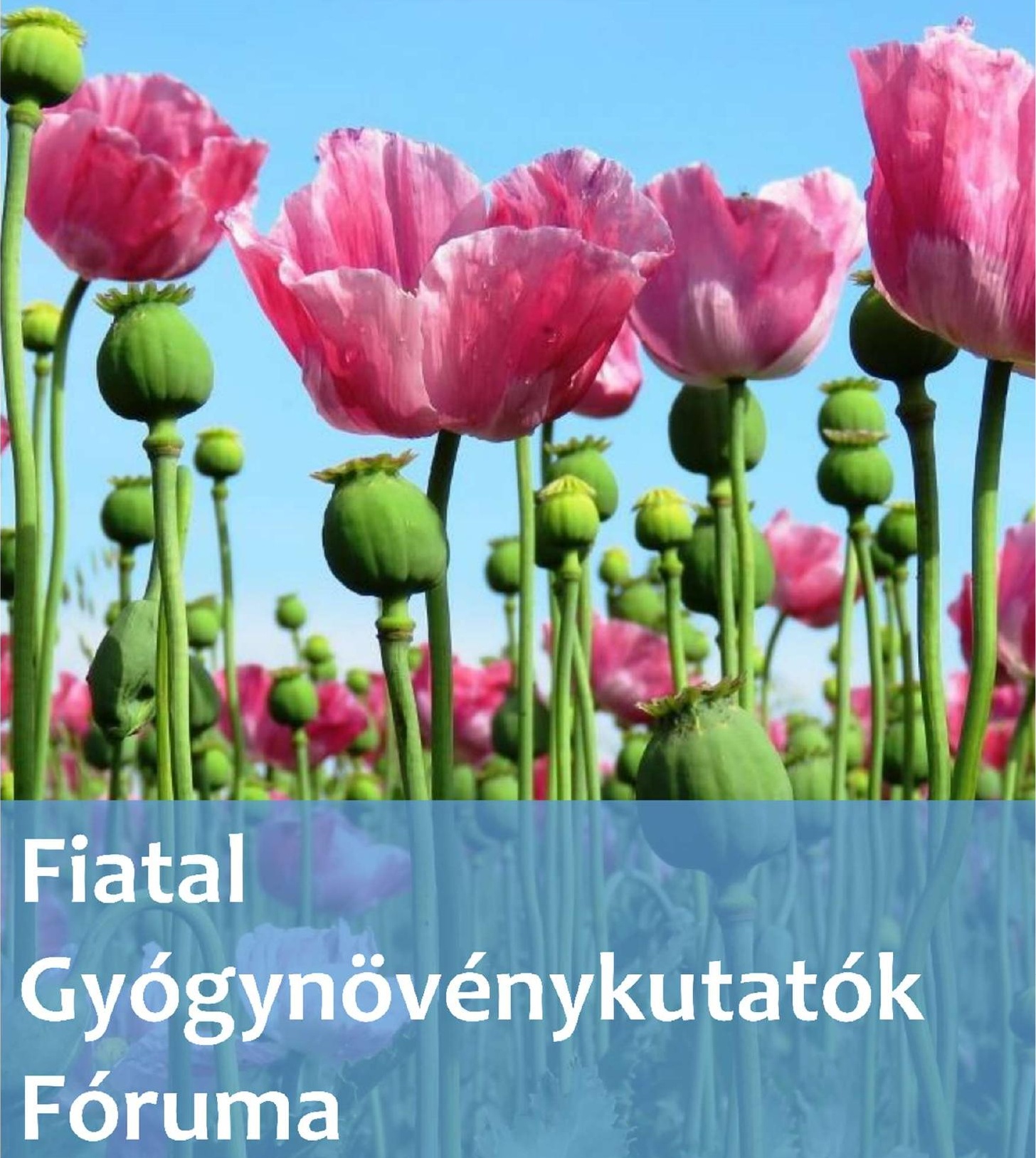

Budakalász, 2017. május 12. | 


\section{In memoriam Dr. Tyihák Ernő 1933-2017.}

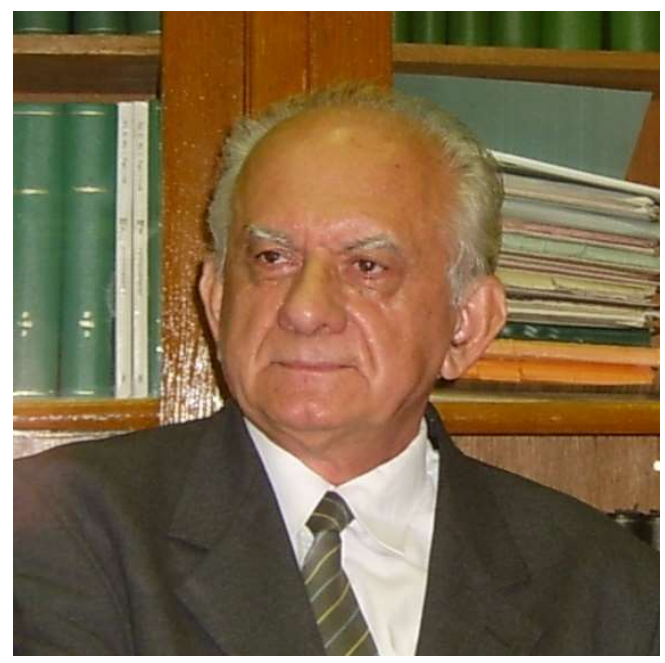

Dr. Tyihák Ernő a kémia tudomány kandidátusa, címzetes egyetemi tanár, az MTA doktora.

Vegyészmérnöki oklevelét 1958-ban szerezte. Az egyetem elvégzése után a Gyógynövény Kutató Intézetben dolgozott 1982-ig. 1978-ban a kémiai tudomány kandidátusa. 1983tól a Magyar Tudományos Akadémia Növényvédelmi Kutatóintézetében

a

Rezisztencia-biológiai és Biokémiai Osztály megszervezésében vett részt. 1994-ben a Magyar Tudományos Akadémia doktora lett. Számos tudományos közlemény szerzője, 25 szabadalom birtokosa. Főbb kutatási témái közé tartozott az illóolajok vizsgálata, tumorgátló anyagok, speciális fehérjék (izopolipeptidek) izolálása, a formaldehidciklus kutatása, a túlnyomásos rétegkromatográfia (OPLC) és a BioAréna kifejlesztése. A Semmelweis Egyetem c. egyetemi docense és a Szegedi Tudományegyetem c. egyetemi tanára volt. Emlékét megőrizzük. 


\title{
FIATAL GYÓGYNÖVÉNYKUTATÓK FÓRUMA
}

\author{
A Magyar Gyógyszerésztudományi Társaság \\ Gyógynövény Szakosztályának tudományos konferenciája
}

Gyógynövénykutató Intézet, Budakalász

2017. május 12.

doi: 10.14232/fgykf.2017.af 



\section{PROGRAM}
9:30-9:40
Megnyitó

\section{ELŐADÁSOK}

ELNÖK: HOHMANN JUDIT

A1 - 9:40-10:00 Pallos József Péter:

A Tradicionális Kínai Medicina (TCM) növényi hatóanyagai

A2 - 10:00-10:20 Könye Rita, Tóth Gergő, Sólyomváry Anna, Mervai Zsolt, Alberti Ágnes, Béni Szabolcs, Boldizsár Imre:

Új, sejtosztódást gátló neo- és szeszkvineolignánok taxonspecifikus felhalmozódása Cirsium fajok terméseiben

A3 - 10:20-10:40 Bús Csaba, Kúsz Norbert, Tóth Barbara, Hohmann Judit, Vasas Andrea:

A Juncus compressus fitokémiai vizsgálata

A4 - 10:40-11:00 Bartha Sámuel Gergely, Papp Nóra, Kopcsányi Márton, Mágó Martin, Kerényi Mónika:

A farkasalma (Aristolochia clematitis L.) antimikrobás hatásának vizsgálata

\section{ELŐADÁSOK}

ELNÖK: ZÁMBORINÉ NÉMETH ÉVA

B1 - 11:20-11:40 Vollár Martin, Szűcs Péter, Marschall Marianna, Zupkó István, Gyovai András, Csupor-Löffler Boglárka, Csupor Dezső:

Hazai mohafajok fitokémiai és farmakológiai vizsgálata

B2 - 11:40-12:00 Détár Enikő, Zámboriné Németh Éva, Szabó Dóra, Pluhár Zsuzsanna:

Magyarországi termesztett levendula (L. angustifolia Mill., L. $x$ intermedia (L.) Emeric) állományok antioxidáns kapacitásának és polifenol mintázatának vizsgálata 
B3 - 12:00-12:20 Riba Milán, Hanyicska Martin, Vasas Gábor:

Nostoc fajok bioaktív metabolitjainak vizsgálata

B4 - 12:20-12:40 Sárközy András, Béni Zoltán, Dékány Miklós, Zomborszki Zoltán Péter, Papp Viktor, Rudolf Kinga, Hohmann Judit, Ványolós Attila:

Az óriás likacsosgomba (Meripilus giganteus Karst.) tartalomanyagainak vizsgálata

B5 - 12:40-13:00 Gampe Nóra, Darcsi András, Kursinszki László, Béni Szabolcs: Izoflavonoid glükozidok béta-aminosav észterei: izolálás és szerkezetmeghatározás

13:15-13:45 Thomas-Nyári Zsófia:

Tyihák Ernőre emlékezünk 


\section{ELŐADÁSKIVONATOK}




\section{A Tradicionális Kínai Medicina (TCM) növényi hatóanyagai}

\section{Pallos József Péter}

Gyógynövénykutató Intézet Kft., 2011 Budakalász, Lupaszigeti út 4.

A TCM, azaz a Hagyományos Kínai Gyógyítás jellemzője, hogy kiterjedten, az egészség tekintetében nemcsak a gyógyszerek, hanem a diagnosztika, a gyógymódok és a betegségmegelőzés összességeként őrizte meg a keleti szemlélet, és a nézetek hagyományait.

$A z$ emberi fejlődéstörténet ívét szépen rajzolja fel a gyógyítás múvészete, melynek folyamatosan megújuló eszközkészlete a régi-új „ósdi” - mégis modern növényi hatóanyagokkal végzett gyógyítás.

A világban, de különösen Európában egyre nagyobb igény mutatkozik a TCM orvoslás és gyógyszerek iránt. Az Európai Gyógyszerkönyv számos TCM drog monográfiát vesz fel, vesz át, adaptál a Kínai Gyógyszerkönyvből. A ma érvényben lévő Európai Gyógyszerkönyvben közel 60 TCM drog szerepel, és külön munkacsoport dolgozik a további cikkelyek adaptációján.

Az Európai Unió piacaira nem kerülhet gyógyszer, növényi gyógyszer, drog, kivonat, hatóanyag vagy készítmény a jogszabályokban meghatározott vizsgálatok, és minőségbiztosítási felszabadítás nélkül, amelyet csak hatóságilag engedélyezett gyártó és/vagy vizsgáló helyek végezhetnek el.

Az előadás célja egy átfogó kép kialakítása az Európai Gyógyszerkönyvben szereplő és a tradicionális kínai gyógyításban használatos gyógynövények minőségi szabályozásáról, ami Európában már szinte nem a jövő, hanem a jelen. 


\section{Új, sejtosztódást gátló neo- és szeszkvineolignánok taxon-specifikus felhalmozódása Cirsium fajok terméseiben}

$\underline{K o ̈ n y e ~ R i t a ~}^{1,2}$, Tóth Gergö ${ }^{3}$, Sólyomváry Anna ${ }^{1}$, Mervai Zsolt ${ }^{4}$, Alberti Ágnes ${ }^{1}$, Béni Szabolcs ${ }^{1}$, Boldizsár Imre

${ }^{1}$ Semmelweis Egyetem, Farmakognóziai Intézet, 1085 Budapest, Üllői út 26.

${ }^{2}$ Eötvös Lóránd Tudományegyetem, Növényszervezettani Tanszék, 1117 Budapest, Pázmány Péter sétány $1 / C$.

${ }^{3}$ Semmelweis Egyetem, Gyógyszerészi Kémiai Intézet, 1092 Budapest, Hőgyes Endre utca 7.

${ }^{4}$ Semmelweis Egyetem, I.sz. Patológiai és Kísérleti Rákkutató Intézet, 1085 Budapest, Üllői út 26.

A lignán (Li), neolignán (NeLi) és szeszkvineolignán (SzeNeLi) másodlagos növényi anyagcseretermékek között értékes, sejtosztódást gátló hatóanyagokat is találunk, melyek hatásosságát már több daganatos sejtvonalon bizonyították. Korábbi eredményeink alapján a Cirsium (aszat) fajok termései nagy mennyiségben halmoznak fel ilyen típusú vegyületeket.

Jelen munkánk célja az eddig még nem vizsgált Cirsium fajok terméseinek fitokémiai jellemzése, különös tekintettel a lignánokra.

A C. rivulare (csermelyaszat) termésében két új természetes vegyületet (a NeLi demetilbalanofonint és a SzeNeLi demetilpikrazmalignánt) azonosítottunk. A nemzetség több fajának termésösszetételét összehasonlítva a Li, NeLi és SzeNeLi szerkezetű vegyületek taxonspecifikus felhalmozódását sikerült kimutatni. Ennek segítségével kiválasztásra kerültek azon Cirsium fajok, amelyek terméséből a lignánok magas hozammal, tiszta formában izolálhatók. Így a $C$. rivulare terméseiből a két új NeLi és SzeNeLi összetevőt (melyek a Cirsium nemzetség Chamaeleon szekciójára jellemzők), míg $C$. eriophorum terméseiből már ismert két NeLi-t (balanofonint és prebalanofonint) és két SzeNeLi-t (pikrazmalignánt és prepikrazmalignánt) nyertük ki. A prebalanofonin és a prepikrazmalignán az Eriolepis szekció jellemző vegyületeinek bizonyultak.

Kimutattuk továbbá az izolált vegyületek sejtosztódásgátló hatását (SW480 vastagbél adenokarcinóma sejtvonalon), valamint a szerkezet-hatás összefüggéseket állapítottunk meg.

Témavezetők: Béni Szabolcs (SE, Farmakognóziai Intézet)

Boldizsár Imre (ELTE, Növényszervezettani Tanszék) 


\section{A Juncus compressus fitokémiai vizsgálata}

\section{Bús Csaba, Kúsz Norbert, Tóth Barbara, Hohmann Judit, Vasas Andrea}

Szegedi Tudományegyetem, Farmakognóziai Intézet, 6720 Szeged, Eötvös u. 6.

A Juncaceae család 7 nemzetségébe közel 500 növényfaj tartozik. Korábbi fitokémiai és farmakológia vizsgálatok során csak igen kisszámú $(n=8)$, szinte kizárólag a Juncus nemzetségbe tartozó fajt tanulmányoztak. A növényekből különböző vegyületcsoportokba tartozó másodlagos anyagcseretermékeket azonosítottak (pl. fenantrének, flavonoidok, terpenoidok), melyek közül kiemelkedő jelentőségúek a figyelemre méltó biológiai aktivitással és szerkezeti változékonysággal rendelkező fenantrének. Több fenantrén rendelkezik in vitro citotoxikus, antimikrobiális, antioxidáns és gyulladáscsökkentő hatással. Mivel a Juncaceae növénycsalád ígéretes fenantrénforrás, ugyanakkor ezidáig a családba tartozó növények kevesebb, mint 2\%át tanulmányozták, ezért a család fajainak kutatása perspektivikus.

Az SZTE Farmakognóziai Intézetében indult kutatási program keretében célul tűztük ki a Kárpát-medencében előforduló, Juncaceae családba tartozó növények fitokémiai és farmakológiai vizsgálatát. Ennek a programnak a részeként végeztük el a korábban még nem vizsgált, Juncus compressus Jacq. másodlagos anyagcseretermékeinek izolálását és szerkezet-meghatározását.

A száraz növényi minta extrakciója metanollal végzett perkolálással történt szobahőmérsékleten, majd ezt követően diklórmetánnal folyadék-folyadék megosztást végeztünk. A szerves fázisból a vegyületek tisztítását többlépéses kromatográfiás eljárás segítségével végeztük el, oszlopkromatográfia, vákuum folyadékkromatográfia, rotációs planárkromatográfia, közepes nyomású folyadékkromatográfia, gélszúrés és nagy hatékonyságú folyadékkromatográfia alkalmazásával. A vegyületek szerkezet-meghatározása NMR spektroszkópiai módszerekkel valamint irodalmi adatokkal való összevetéssel történt.

Munkánk eredményeként a $J$. compressusból három vinilszubsztituált fenantrént, az effusolt, a 7-hidroxi-1-metil-2-metoxi-5-vinil-9,10-dihidrofenantrént, valamint egy új természetes vegyületet, a kompresszin A-t azonosítottuk.

Köszönetnyilvánítás: A munkát a GINOP-2.3.2-15-2016-00012 pályázat támogatta.

Témavezető: $\quad$ Vasas Andrea (SZTE, Farmakognóziai Intézet) 


\section{A farkasalma (Aristolochia clematitis L.) antimikrobás hatásának vizsgálata}

\section{Bartha Sámuel Gergely ${ }^{1}$, Papp Nóra ${ }^{1}$, Kopcsányi Márton², Mágó Martin²,} Kerényi Mónika²

${ }^{1}$ Pécsi Tudományegyetem, Farmakognóziai Intézet, 7624 Pécs, Rókus u. 2.

${ }^{2}$ Pécsi Tudományegyetem, Orvosi Mikrobiológiai és Immunitástani Intézet, 7624 Pécs, Szigeti út 12.

Erdélyben napjainkban is élnek tradicionális gyógymódok, amelyek generációról generációra öröklődnek. Kutatómunkánk során Székelyföldön és a Szilágyságban végeztünk etnobotanikai gyújtést (2010-2016), majd a feljegyzett gyógynövények helyi alkalmazását összevetettük tudományos adatbázisok adataival. Így jelöltük ki további vizsgálatra a farkasalmát (Aristolochia clematitis, Aristolochiaceae); levelét - korábbi adatokhoz hasonlóan - az adatközlők 78\%-a említette a helyi állatgyógyászatban külsőleg sebek kezelésére. Jelen munkánk célja a növény antimikrobás hatásának tesztelése volt.

A növény levelének, szárának és gyökerének metanolos, hexános, kloroformos, etil-acetátos, butanolos és vizes kivonatát vizsgáltuk kémcsőhígításos módszerrel az alábbi törzsek esetében: Staphylococcus aureus (ATCC ${ }^{\circledR}$ 25923),

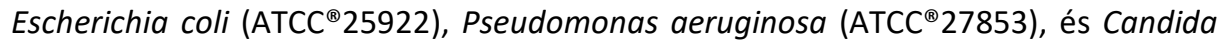
albicans (ATCC ${ }^{\circledR} 90028$ ).

A növény minden vizsgált részének vizes kivonata gátolta a $S$. aureus, $P$. aeruginosa és $C$. albicans, a szár és a levél metanolos kivonata a $P$. aeruginosa szaporodását. Vizes kivonatok esetén a növény gyökerének kivonata nagyobb gátlást fejtett ki a levél és szár kivonatokkal szemben.

Előzetes irodalmi adatok alapján a kloroformos fázissal kivonásra kerül a fajban előforduló arisztolochiasav, így valószínúsíthető, hogy az antimikrobás hatásúnak bizonyult vizes fázis a komponenst kis mértékben tartalmazza (erre vonatkozó mérést még nem végeztünk). A vizes oldatok farmakokinetikai szempontból előnyösebbek, ami ígéretes lehet az alkalmazás szempontjából. További vizsgálatokat tervezünk a növény komponenseinek meghatározására, az arisztolochiasav mennyiségi mérésére az egyes fázisokban, illetve a kivonatok klinikai törzsekre gyakorolt hatására.

Témavezetők: $\quad$ Papp Nóra (PTE, Farmakognóziai Intézet)

Kerényi Mónika (PTE, Orvosi Mikrobiológiai és Immunitástani Intézet) 


\title{
Hazai mohafajok fitokémiai és farmakológiai vizsgálata
}

\author{
Vollár Martin ${ }^{1,2}$, Szücs Péter ${ }^{3}$, Marschall Marianna $^{3}$, Zupkó István $^{4}$, Gyovai András 4 , \\ Csupor-Löffler Boglárka ${ }^{1,2}$, Csupor Dezsö ${ }^{1,2}$ \\ ${ }^{1}$ Szegedi Tudományegyetem, Farmakognóziai Intézet, 6720 Szeged, Eötvös u. 6. \\ ${ }^{2}$ Szegedi Tudományegyetem, Természetes Vegyületek Interdiszciplináris Központja, 6720 Szeged, \\ Eötvös u. 6. \\ ${ }^{3}$ Eszterházy Károly Egyetem, Növénytani és Növényélettani Tanszék, 3300 Eger, Lányka u. 6. \\ ${ }^{4}$ Szegedi Tudományegyetem, Gyógyszerhatástani és Biofarmáciai Intézet, 6720 Szeged, Eötvös u. 6.
}

A virágos növények mintegy 10-15\%-át vizsgálták valamilyen mértékben fitokémiai és farmakológiai szempontból, azonban a virágtalan, spórás felsőbbrendű növények közé tartozó mohákra kisebb tudományos figyelem irányult. Ugyanakkor a mohák másodlagos anyagcseretermékeinek vizsgálata érdeklődésre tarthat számot, mivel kór- és károkozókkal szembeni védekezésük hátterében citotoxikus és/vagy antimikróbás hatású vegyületek állhatnak.

Különböző mohafajokat elsősorban az ázsiai népi gyógyászatban alkalmaztak. Az amerikai őslakosok is használtak mohakivonatot hamuval keverve sebek kezelésére, Kínában pedig a mai napig megtalálhatók a gyógyászatban, külsőlegesen és belsőlegesen alkalmazva egyaránt. Az eddig vizsgált fajok jellemző vegyületei közé tartoznak mono- és szeszkviterpének, aromás észterek, növényi savak. Nagy felfedezésnek számít a korábban a Maytenus serrata kérgéből származó tubulingátló hatású maytanzinoidok azonosítása mohákból.

A hazai mohaflóra 659 fajt tartalmaz, ebből 58 fajt vizsgáltunk antiproliferatív és antimikrobiális hatásra in vitro szürővizsgálatban. Legaktívabbnak a Paraleucobryum longifolium bizonyult. Célunk ebből a fajból az aktív vegyületek izolálása és azonosítása. A preparatív növénykémiai munka során oszlopkromatográfiát, preparatív rétegkromatográfiát, rotációs planárkromatográfiát, közepes és nagy nyomású folyadékkromatográfiát alkalmazunk, normál és fordított fázisokon egyaránt. A szerkezetmeghatározás mágneses magrezonancia és tömegspektrometria segítségével történik.

Köszönetnyilvánítás: A kutatásokat az NKFI OTKA 115796 számú pályázati támogatása teszi lehetővé. A kutatás a Bolyai János Kutatási Ösztöndíj segítségével valósult meg.

Témavezető: $\quad$ Csupor Dezső (SZTE, Farmakognóziai Intézet) 


\section{Magyarországi termesztett levendula (L. angustifolia Mill., L. x intermedia (L.) Emeric) állományok antioxidáns kapacitásának és polifenol mintázatának vizsgálata}

\section{Détár Enikő, Zámboriné Németh Éva, Szabó Dóra, Pluhár Zsuzsanna}

Szent István Egyetem, Kertészettudományi Kar, Gyógy- és Aromanövények Tanszék, 1118 Budapest, Villányi út 29-43.

A levendula fajok világszerte nagy jelentőségű illóolajos gyógynövényként ismertek, érdemes azonban figyelmet fordítani a kevéssé feltárt, fenoloid típusú vegyületeikre is. Számos irodalmi adat igazolja, hogy a levendula beltartalmi anyagainak alakulását elsődlegesen a genotípus határozza meg, azonban emellett számos környezeti tényező (termőterület, éghajlati adottságok) is befolyásolhatja. Hazánkban az elmúlt években megnövekedett az érdeklődés a levendula termesztése iránt, ugyanakkor kevés információ áll rendelkezésre a fajták beltartalmi jellemzőit illetően. Ezért kísérleteinkben 4 eltérő adottságú magyarországi termőterületről (Budapest/Soroksár, Tihany, Dörgicse, Szomód) gyűjtöttünk mintákat másodvirágzásban levő levendula állományokból 2016 októberében. Hét $L$. angustifolia és három $L$. $x$ intermedia fajta előzetes értékelésére került sor, levél és virág minták alapján. Az antioxidáns-kapacitás és az össz-polifenol tartalom meghatározása vizes kivonatokból történt, 15-18 ismétlésben. Megállapítottuk, hogy az antioxidáns-kapacitás vizsgálatakor kapott adatok korrelálnak az össz-polifenol értékekkel. A legmagasabb értékeket a hibrid levendula fajták leveleiben mértük, különösen a soroksári L. $x$ intermedia 'Judit' esetében (235,53 mg ASE/g sz.a. és 179,22 mg GSE/g sz.a.). A termőhelyek összehasonlításakor kimutattuk, hogy a Szomódon gyűjtött 'Munstead' (159,28 mg ASE/g sz.a.), 'Hidcote' (159,86 mg ASE/g sz.a.) és 'Grappenhall' (201,64 mg ASE/g sz.a.) fajták mintáiban nagyobb antioxidáns aktivitás mérhető, mint ugyanezen fajtáknál Dörgicsén. A továbbiakban szükségesnek tartjuk e vizsgálatok elvégzését nyáron, a fő virágzás időszakában, valamint a termőhelyi hatások pontosabb értékeléséhez a talaj- és időjárási tényezők elemzését is. A FRAP módszer mellett az antioxidáns kapacitás értékelését a DPPH-módszerrel is ki kívánjuk egészíteni.

Köszönetnyilvánítás: Ezúton fejezzük ki köszönetünket Dr. Demján Ildikónak a dörgicsei Levendula Major Kft. ügyvezetőjének, illetve Tóth Józsefnek, a Szomódi Levendulás vezetőjének a minták rendelkezésünkre bocsátásáért.

Témavezető: Pluhár Zsuzsanna (SZIE, Gyógy-és Aromanövények Tanszék) 


\title{
Nostoc fajok bioaktív metabolitjainak vizsgálata
}

\author{
Riba Milán, Hanyicska Martin, Vasas Gábor
}

Debreceni Egyetem, Növénytani Tanszék, 4032 Debrecen, Egyetem tér 1.

A cianobaktériumok által termelt bioaktív anyagoknak egyre nagyobb tudományos figyelmet szentelnek. A szerkezetileg igen különböző metabolit csoportokhoz sokféle biológiai hatás köthető. Nostoc fajokból korábban már számos antimikrobiális, citotoxikus, tumorellenes enzimgátló, membránstabilitást befolyásoló anyagcsere terméket írtak le. Napjainkban az ismert bioaktív metabolitok száma gyors növekedésnek indult, és farmakológia jelentőségük is egyre nagyobb. Munkánk során az Alföldről származó Nostoc sejtvonalakban 4 peptid típusú bioaktív metabolit csoportot azonosítottunk HPLC-MS/MS módszerrel. A csoportokon belül több, eddig ismeretlen variánst is sikerült teljesen vagy részben azonosítanunk. Nostoginin típusú metabolitok közül 11 új és 1 már ismert variánst határoztunk meg. Ezek a lineáris oligopeptidek aminoproteáz és angiotenzin konvertáló enzim gátló hatásuk miatt elsősorban a kardiovaszkuláris megbetegedések kezelésében játszhatnak fontos szerepet. Sejtvonalainkban 18 anabaenopeptin variánst sikerült részben azonosítanunk. Ezek a ciklikus hexapeptidek protein foszfatázok és proteolitikus enzimek (tripszin, kimotripszin, elasztáz, karboxipeptidáz-A) működését gátolják. Egyetlen izolátum esetében előforduló nostopeptolid A1/A3 egy ciklikus depsipeptid. Ezen csoport több tagja citotoxikus, antifungális valamint peptidáz gátló hatású, illetve egyes variánsok antitoxikusak, gátolják a microcystinek által indukált apoptózist májsejtekben. A leggyakrabban előforduló metabolitok a banyaside-ok, mintáink több mint felében jelentek meg variánsaik. Ezek a glikopeptidek kevésbé ismertek, proteolitikus enzimek múködését gátolják. 13 variáns szerkezetét sikerült részben vagy egészében meghatároznunk.

Témavezető: Vasas Gábor (DE, Növénytani Tanszék) 


\section{Az óriás likacsosgomba (Meripilus giganteus Karst.) tartalomanyagainak vizsgálata}

Sárközy András ${ }^{1}$, Béni Zoltán², Dékány Miklós², Zomborszki Zoltán Péter ${ }^{1}$, Papp Viktor ${ }^{3}$, Rudolf Kinga ${ }^{4}$, Hohmann Judit ${ }^{1}$, Ványolós Attila ${ }^{1}$

${ }^{1}$ Szegedi Tudományegyetem, Farmakognóziai Intézet, 6720 Szeged, Eötvös u. 6.

${ }^{2}$ Richter Gedeon Nyrt., 1103 Budapest, Gyömröi út 19-21.

${ }^{3}$ Szent István Egyetem, Kertészettudományi Kar, 1118 Budapest, Villány út 29-43.

${ }^{4}$ Kaposvári Egyetem, Agrár- és Környezettudományi Kar, 7400 Kaposvár, Guba Sándor u. 40.

Az óriás likacsosgomba (Meripilus giganteus) a Meripilaceae család hazánkban legelterjedtebb tagja. A faj leginkább bükkösökben fordul elő, parazita vagy szaprofita életmódot folytat. Bár fiatalon ehető, nem ízletes, emiatt nem széleskörűen gyǔjtött gomba. Korábbi farmakológiai vizsgálatok eredményei alapján az óriás likacsosgomba kivonata antibakteriális és antioxidáns hatással rendelkezik, azonban a tapasztalt hatásért felelős tartalomanyagokról igen kevés információval rendelkezünk. Munkánk célja volt az óriás likacsosgomba biológiailag aktív vegyületeinek izolálása, szerkezetmeghatározása és farmakológiai hatásának vizsgálata.

A vizsgálandó mintát több észak-magyarországi lelőhelyen gyűjtöttük 2016 őszén. A 12 kg gombát szobahőmérsékleten metanollal kivontuk, majd $n$-hexánnal, ill. kloroformmal folyadék-folyadék extrakciót végeztünk. Ezt követően a kloroformos frakcióból különböző elválasztástechnikai módszerek alkalmazásával (flash kromatográfia, normál és fordított fázisú HPLC, preparatív rétegkromatográfia) 6 komponenst izoláltuk, amelyek szerkezet-meghatározása spektroszkópiai módszerek (NMR és MS) segítségével történt. Az azonosított összetevők között ergosztán vázas és ceramid típusú vegyületeket, illetve hidroxi-zsírsavakat is találtunk. A komponensek antioxidáns hatását ORAC és DPPH módszerekkel vizsgáltuk. Munkánk folytatásaként a vegyületek antibakteriális hatásának vizsgálatát és a hexános frakció jellegzetes komponenseinek azonosítását tervezzük.

Témavezetők: Ványolós Attila (SZTE, Farmakognóziai Intézet) 


\section{Izoflavonoid glükozidok béta-aminosav észterei: izolálás és szerkezetmeghatározás}

\section{Gampe Nóra, Darcsi András, Kursinszki László, Béni Szabolcs}

Semmelweis Egyetem, Farmakognóziai Intézet, 1085 Budapest Üllői út 26

A tövises iglice a népgyógyászatban régóta ismert növény, a gyökeréből készült teát vizelethajtásra és húgyúti fertőzések kezelésére alkalmazzák; az iglice gyökér mind a Magyar mind az Európai Gyógyszerkönyvben hivatalos. Az Ononis spinosa a pillangósvirágúak családjába tartozik, amelynek jellemző másodlagos anyagcseretermékei az izoflavonoidok. Korábbi munkánk során a gyökér vizesmetanolos kivonatának teljes izoflavonoid profilját vizsgáltuk, és megállapítottuk, hogy az Ononidis radix ritka dihidroizoflavonoidokat és pterokarpánokat is tartalmaz. A pozitív ionizációs módban végzett HPLC-MS/MS mérések során karakterisztikus nitrogén-tartalmú vegyületeket figyeltünk meg. Az MS/MS spektrumok alapján ezek az ismert izoflavonoid glükozidoknak egy nitrogéntartalmú molekulával képzett származékai. Flavonoidok esetén ismertek ugyan nitrogéntartalmú származékok, de izoflavonoidoknál ilyen származékokat még nem közöltek. Mivel a növényben eddig nem írtak le nitrogéntartalmú másodlagos anyagcseretermékeket, ezért célul tűztük ki ezek szerkezetének pontos meghatározását. Kationcserélő oszlopon történő dúsítást, majd preparatív HPLC-vel való tisztítást követően, NMR spektroszkópia segítségével meghatározhattuk a vegyületek pontos szerkezetét. Eredményeink alapján a növényben megtalálható hatféle izoflavonoid glükozid piperidin-2-ecetsavval képzett észterét sikerült azonosítanunk, amelyek mellett, mint minor komponensek, a pirrolidin-2-ecetsavszármazékok is megjelennek. Ezek a béta-aminosavak a növényvilágban csak elvétve fordulnak elő, bioszintézisük és funkciójuk eddig nem ismert.

Témavezetők: Kursinszki László és Béni Szabolcs (SE, Farmakognóziai Intézet) 


A rendezvény támogatója a Gyógynövénykutató Intézet

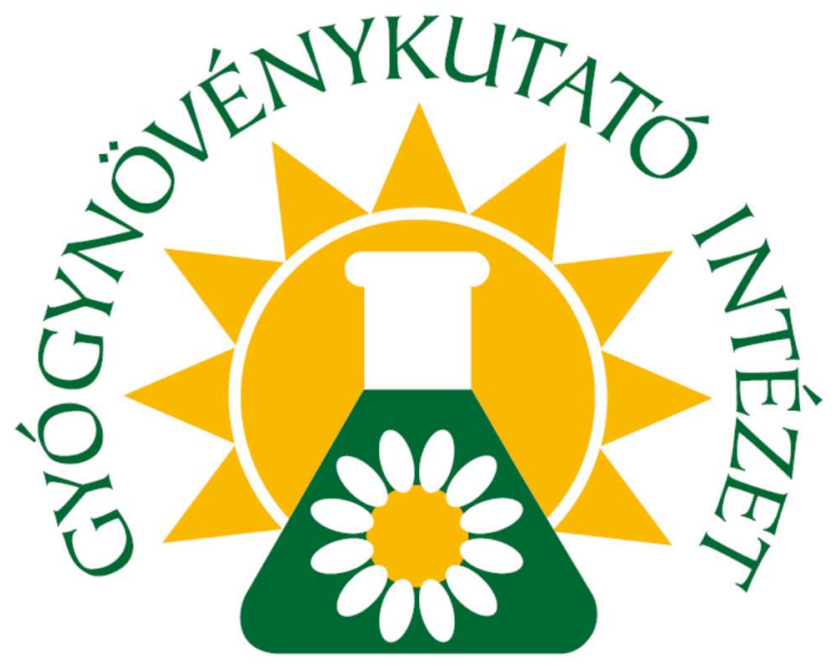

Alapítva: 1915

Kiadja a Magyar Gyógyszerésztudományi Társaság Gyógynövény Szakosztálya

Szerkesztők: Csupor Dezső, Rédei Dóra, Kiss Tivadar

Szeged, 2017 
Papaver somniferum, az Év Gyógynövénye 2017-ben www.evgyogynovenye.hu

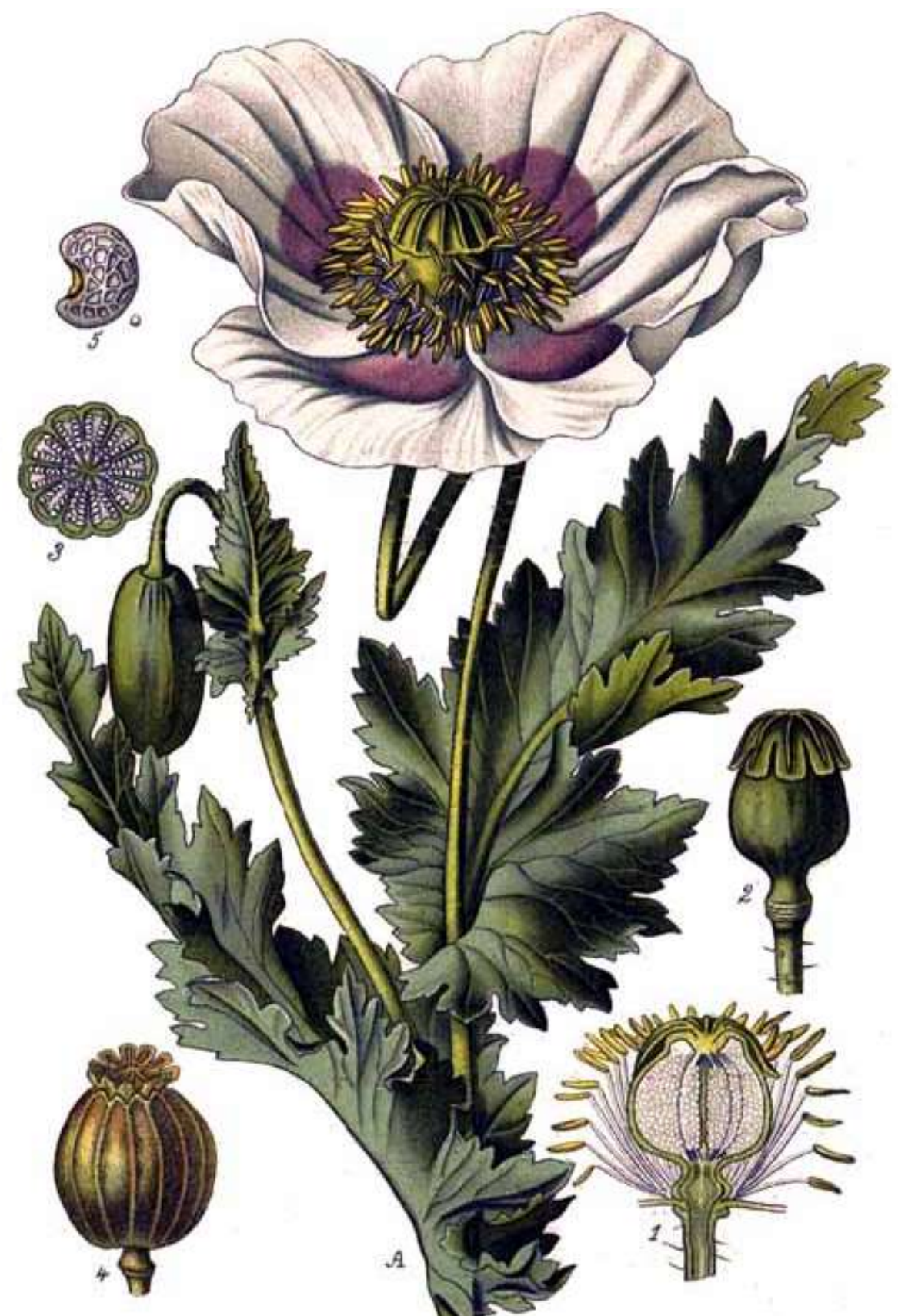

